\title{
Regional Analysis: Differences in Emission-Intensity Due to Differences in Economic Structure or Environmental Efficiency?
}

\author{
Maarten van Rossum (Corresponding author) \\ Statistics Netherlands (Note 1) \\ PO box 24500, 2490 HA, The Hague, The Netherlands \\ Tel: 31-0-703-374-109 E-mail:m.vanrossum@cbs.nl \\ Marije van de Grift \\ Statistics Netherlands (Note 1) \\ PO box 24500, 2490 HA, The Hague, The Netherlands \\ Tel: 31-0-703-374-189 E-mail: m.vandegrift@cbs.nl
}

\begin{abstract}
The economy is a complex system with many aspects having different interrelated dimensions. Many of these different aspects of the economy may have consequences for the quality of water. Therefore a clear but complex link exists between the economy and the quality of water. This relationship is currently an important issue in estimating the costs of implementing the Water Framework Directive. There are many mechanisms by which the Water Framework Directive affects water quality and the economy. The Water Framework Directive sets water quality targets at river basin level. This is partly explained by the fact that water pollution is very much a local environmental problem. Between river basins exist large differences in emissions to water and economic activity. As a result, the emission-intensity, here defined as the ratio between emissions and value added, differs between river basins. This paper tries to give an answer to why there are differences in emission-intensity between river basins in The Netherlands. In doing so, we will focus on differences in economic structure and environmental efficiency.
\end{abstract}

Keywords: Water pollution, Water accounts, Emission-intensity, Economic structure, Environmental efficiency

\section{Introduction}

Sustainable economic development is an increasingly important issue among policymakers and the public. There is thus a high demand for statistics that can support the measurement and analysis of sustainable development. The system of integrated environmental accounts, also known as SEEA (UN, 2003), is a useful tool for monitoring, measuring and analyzing the relationship between environmental policies and the economy by providing consistent time series of data, tables and accounts. The SEEA is a satellite system of the System of National accounts. It brings together economic and environmental information in a comprehensive framework to measure the contribution of the environment to the economy and the impact of the economy on the environment. Specific accounts cover natural resources such as oil and gas, material flows, air emissions, water emissions, waste, and environmental expenditure. At international level the water accounting framework 'the System of Environmental-Economic Accounting for Water', commonly referred to as SEEAW, has been prepared by the United Nations Statistics Division (UNSD, 2006). The SEEAW is a conceptual framework for the organization of physical and economic information related to water using concepts, definitions and classifications consistent to those of the System of National Accounts 1993 (UN, 1993). The SEEAW framework is an elaboration of that in the handbook Integrated Environmental and Economic Accounting 2003 (UN, 2003).

In the Netherlands, the economic framework National Accounting Matrix (NAM) has also been extended with satellite accounts for the environment. These satellite accounts describe the relationship between environmental pressure and added value for different economic sectors in the economy (NAMEA). A further specification of NAMEA (De Haan, 1994) for water issues is the satellite account Water Accounts, also known as NAMWA (De Haan, 1997) (Note 2). NAMWA provides information about the connection between the physical water system and the economy at national and river basin scale. NAMWARIB is developed in order to provide information at river basin level (Brouwer et al., 
2005). NAMWARIB provides economic and environmental related information at the level of four main river basin districts in the Netherlands; Rhine (Rijn), Meuse (Maas), Scheldt (Schelde) and Ems (Eems). In view of the fact that the Rhine basin covers approximately 70 percent of the entire Dutch territory, this basin is furthermore split into four sub regions: North, West, East and Centre. The Dutch river basin districts are presented in figure 1.

In this paper we make use of the emission accounts at river basin level which provide information on the release of pollutants in wastewater in physical units and of the economic information at river basin level which are both provided by NAMWARIB. The importance of these accounts is strengthened by the introduction of the European Water Framework Directive (WFD). The WFD states that all domestic waters should meet certain targets by 2015, as well in quality as in quantity.

In this paper the differences in emission-intensity, here defined as the ratio between emissions and value added between regions, are investigated. Data has been used on emissions and economic variables for 58 different sectors in the economy. We will try to indicate whether the differences in emission intensity can be traced back to differences in structure of the economy or to differences in environmental efficiency of industries. This analysis is done with use of the so called 'shift share methodology'. This methodology has been used in the 1960s to explain regional differences in productivity and employment (Dunn, 1960). Here we want to explain regional differences in emission-intensities. The specific method we used is based upon the work of Mazzanti \& Montini (2009) and Esteban (2000).

First, we will concentrate on macro figures on emissions and value added. Subsequently, we will have a look at the data on sector level. Next we will present the methodology used to trace back differences in emission intensity due to economic structure and/or environmental efficiency. After presenting the results we get to the conclusion.

\section{Data on emissions and the economy at macro and sector level}

The two most important groups of substances causing environmental problems are heavy metals and nutrients (phosphorus and nitrogen). Heavy metals, like arsenic, cadmium, chrome, copper, mercury, lead, nickel and zinc are natural to some extend, but are toxic in high concentrations. An excess amount of phosphorus and nitrogen in the water causes algae and duckweed to grow disproportional, which can cause certain species of fish, high water plants and other organisms to die off (CBS, 2008). In the NAMWA, the emission of nutrients and heavy metals to the water are allocated to the economic activity which they cause, based on the 'residents' principle. One important pillar for making reliable water emission accounts is the availability of a consistent time series of water emission data. In the Netherlands, these data on water emissions are compiled by a number of governmental institutions working together in the framework of the Pollutant Release and Transfer Register (PRTR). Statistics Netherlands is one of the partners in this project. The database of the PRTR is situated at the Netherlands Environmental Assessment Agency and contains all identified emissions to water, air and soil within the Netherlands territory. Emissions can be presented for a large selection of sources like industry branches, consumers, transport traffic and agriculture. The database facilitates presentation of regional data; for water emissions in particular per water quality management authority (water board) or per Water Framework Directive (sub) river basin. The regional data are accessible for the general public via the website www.emissieregistratie.nl. Part of total emissions is reported by the companies themselves via environmental reports and part of the emissions is estimated by means of calibrating techniques. The mentioned website supplies information on methods for estimating emissions to water.

In figure 2, value added and emissions to water in 2005 for the various river basins are presented. The largest part of value added in 2005 is created in Rhine-West (50 percent of total value added) while the smallest parts are created in river basins Ems and Scheldt (only less than three percent). Rhine-West is responsible for 45 percent of total emissions while the river basins Ems and Scheldt are responsible for 6 and 7 percent of total emissions in the Netherlands.

Viewed nationally, the emissions of heavy metal equivalents (Adriaanse, 1993) to water by companies in the Netherlands have decreased constantly in the period 1995-2005. At the same time, the economy has grown quite rapidly. As a result, the emission intensity had decreased substantially. In other words, environmental performance of companies and institutions has improved substantially in this time period. However, with regard to the river basins, there are large differences between economic growth and emissions of heavy metals. In figure 3 , growth in value added and reduction in emissions for the different river basins is presented. In the period 1995-2005 economic growth in the river basin Rhine Central was 39 percent, while in the Ems river basin it was only 8 percent. In the Ems area emissions of heavy metals fell only slightly, while emissions in Rhine West dropped considerably. As a result, the emission intensity dropped the most in the Rhine West area. In spite of high economic growth in this region, emissions decreased substantially. One reason for this was the reorganisation of the fertiliser industry in the area. This industry emitted large amounts of heavy metals. The decrease in emission intensity was smallest in the Ems river basin. The emission-intensity is calculated at river basin level for 1995 and 2005 and this is presented in figure 4.

The emission-intensities of the different regions can be deducted with the emission-intensity of the Netherlands (based upon the sum of the regions). It then becomes clear how the region is doing in terms of emission-intensity in 
comparison to the national average. Figure 5 displays the difference in emission-intensity of the regions compared with the Netherlands for the period 1995-2005. Most regions are not performing as well as the national average. These regions are Scheldt, Ems, Rhine-East, Rhine-Central and Rhine-North. The regions Rhine-West and Meuse are performing better than the Dutch average.

It is even more interesting to look at sector level by analysing why emissions are high in some river basins and low in other river basins. The distribution of value added and emissions to water over economic sectors differs a lot between river basins. Tables 1 and 2 give a clear picture of the share of value added created by a particular sector in the economy and the related emissions to water (measured in heavy metal-equivalents).

\section{Methodology}

The main question in this paper is how differences in emission-intensity between regions can be explained and to what extent certain economic sectors play a role in explaining these differences. In explaining differences in emission-intensity, we concentrate on economic efficiency, economic structure and different sectors.

Data is used on emissions and economic variables for 58 different sectors (aggregated to 3 sectors) in the economy. Then we will try to indicate whether the differences in emission intensity can be traced back to differences in structure of the economy or to differences in environmental efficiency of industries. This analysis is done with use of the so called 'shift share methodology'. This methodology has been used in the 1960s by Dunn to explain regional differences in productivity and employment. Here we want to explain regional differences in emission-intensities. The specific method used here is based upon the work of Mazzanti \& Montini (2009) and Esteban (2000).

This formulated problem is mathematically written as follows:

$D_{r-n l}=X_{r}-X_{n l}$, stand for the difference in emission intensity between a region and the Netherlands where,

$X_{r}=\sum_{i n} P_{r}^{i n} X_{r}^{i n}$, emission-intensity region $r$

$X_{n l}=\sum_{i n} P_{n l}^{i n} X_{n l}^{i n}$, emission-intensity Netherlands

$X_{r}^{i n}=\frac{E_{r}^{i n}}{Y_{r}^{i n}}$, emission intensity industry $i n$ in region $r$

$X_{n l}^{i n}=\frac{E_{n l}^{i n}}{Y_{n l}^{i n}}$, emission intensity industry in in the Netherlands

$P_{r}^{i n}=\frac{Y_{r}^{i n}}{Y_{r}}$, share in total value added of industry in in region $r$

$P_{n l}^{i n}=\frac{Y_{n l}^{i n}}{Y_{n l}}$, share in total value added of industry in in the Netherlands

where,

- $X_{r}=$ emission intensity region $r$

- $X_{n l}=$ emission intensity the Netherlands

- $E=$ emissions to water $\mathrm{E}$

- $Y=$ value added in basic prices

- $\quad n l$ stands for the Netherlands

- $r$ stands for region $r$

- $\quad$ in stands for industry

- $\quad$ Empirical model for explaining differences in emission-intensity between regions:

$D_{r-n l}=\beta_{1} Q_{r}^{A} M_{r}^{A}+\beta_{2} Q_{r}^{I} M_{r}^{I}+\beta_{3} Q_{r}^{S} M_{r}^{S}+\beta_{4} Z_{r}^{A} P_{r}^{A}+\beta_{5} Z_{r}^{I} P_{r}^{I}+\beta_{6} Z_{r}^{S} P_{r}^{S}+c$

Where,

$M_{r}^{A}=\sum_{A}\left(P_{r}^{A}-P_{n l}^{A}\right) X^{A}$, represents the industry mix effect of agriculture. 
The industry mix effect of manufacturing (I) and Services (S) is calculated using the same line of reasoning as for agriculture (A) (see appendix 1).

$P_{r}^{A}=\sum_{A} P_{n l}{ }^{A}\left(X_{r}^{A}-X_{n l}{ }^{A}\right)$, represents the efficiency effect of agriculture.

The efficiency effect of manufacturing (I) and Services (S) is calculated using the same line of reasoning as for agriculture (A) (see appendix 1).

$Q_{r}^{A}=\frac{E_{r}^{A}}{E_{r}}$, represents the share of emissions of agriculture in total emissions in region $r$.

This share of emissions is also calculated for manufacturing (I) and Services (S) (see appendix 1).

$Z_{r}^{A}=\frac{Y_{r}^{A}}{Y_{r}}$, represents the share of value added of agriculture in total value added in region $r$.

This share of value added is also calculated for manufacturing (I) and Services (S) (see appendix 1).

The data entered in the model are the emissions to surface water and waste water over the years 1995, 2000, 2004 and 2005. The emitted heavy metals are arsenic, cadmium, chrome, copper, mercury, lead, nickel and zinc. The emitted nutrients are phosphor and nitrogen. The included river basins are Meuse, Scheldt, Ems, Rhine-West, Rhine-East, Rhine-North, Rhine-Centre. Data on emissions and economic variables is available for 58 different economic sectors. This results in $280(10 \times 4 \times 7)$ unique data points.

\section{Results and discussion}

Differences in emission-intensity are explored using two tools, namely the regression analysis, whose results are presented in table 3, and a more intuitive graphical tool. This graphical tool represents emission-intensities at sector level (heavy metal equivalents). This has been done for three sectors: Agriculture, Manufacturing and Services (aggregated from the 58 sectors). Together these sectors form the total economy of a particular region. These sector-specific emission-intensities can also be deducted with the Dutch average for the particular sector under consideration. By means of these tools, the differences in emission-intensity between river basins are explained. This explanation is at sector level. Agriculture, manufacturing and services will subsequently be discussed hereafter.

\subsection{Agriculture}

Differences between regions in the economic structure of agriculture can have a significant influence on the difference in emission-intensity between regions. Agriculture can be represented by a lot of horticulture in one region (e.a. Rhine West), while in the other region arable farming is strongly represented (e.a Rhine North). Arable farming is on average more emission-intensive than horticulture. In order to explain differences in overall emission-intensity, differences in the structure of agriculture can sometimes be a significant explaining factor for some toxic substances. For the substances copper, lead, nickel, phosphorus and nitrogen the structure of agriculture is a significant factor in explaining differences in emission-intensities between regions.

A difference in environmental efficiency is also an explaining factor for differences in emission-intensities between regions. At industry level, one can compare environmental efficiency between regions. For example, arable farming in region A emits per euro value added more emissions to water than arable farming in region B. Accordingly, arable farming in region A is performing in a less environmental friendly way than arable farming in region $\mathrm{B}$. In other words, environmental performance of arable farming in region A is worse than in region B. For the substances cadmium, lead, nickel, zinc, phosphorus and nitrogen holds that differences in environmental performance is a significant explaining factor for the differences in emission-intensity between regions.

The graphical tool for agriculture is presented in figure 6. This figure presents pollution per euro added value for different river basins in the years 1995, 2000 and 2005. Considering agriculture, the emission-intensity in the Meuse region is smaller than the Dutch average. In the Meuse region, environmental regulation related to manure treatment is very strict (LEI, 2006). This is because there are a lot of sandy soils in the Meuse region which are very vulnerable for run-off of heavy metals and nutrients. Life stock activities in this area are very intensive and are responsible for a lot of value added in this area. A large part of the produced manure is transported to areas other than Meuse (CBS, 2007).The manure intensive sector, life stock farming, thus transports its environmental problems to other regions.

In Rhine West, the emission intensity is lower than the Dutch average as well. This is explained by the large horticulture sector in this area. This sector is creating a lot of value added while emissions to water are relatively small. In contrast, arable farming is relatively large in the Ems and Rhine North areas. This sub sector of agriculture creates relatively little value added while the activities go along with a lot of emissions to water indirectly by the run-off of agricultural land to surface water. 


\subsection{Manufacturing}

Differences between regions in the economic structure of manufacturing can have a significant influence on the difference in emission-intensity too. Manufacturing can strongly be represented by for example the chemical and metal sector in one region while in the other region printing and publishing is strongly represented. The chemical and metal sectors are more emission-intensive than for example printing and publishing on average. In order to explain differences in emission-intensity, differences in the structure of manufacturing can be a significant explaining factor. For the substances arsenic, cadmium and copper hold that the structure of manufacturing is a significant factor in explaining differences in emission-intensities between regions. For the other substances hold that differences in the structure of manufacturing is not significantly explaining the differences in emission-intensity. For the substances cadmium, mercury, lead and phosphorus holds that differences in environmental performance in manufacturing is a significant explaining factor for the difference in emission-intensity.

The graphical tool for manufacturing is presented in figure 7. This figure presents pollution per euro added value for the various river basins in the years 1995, 2000 and 2005. The manufacturing sector in river basin Meuse is less emission intensive than the Dutch average (see figure 7). However, the environmental advantage of river basin Meuse has declined over time. This is displayed by the conversion of Meuse's emission-intensity to the Dutch average over time. Emission intensity in Rhine West was higher than the Dutch average in 1995, but hereafter Rhine West's emission intensity improved due to the reorganisation of the fertiliser industry. Emissions reduced sharply while value added declined only slightly. Manufacturing in river basins Ems and Scheldt emitted more emissions to water per euro value added created than the Dutch average. This is due to fact that the chemical sector is quite big and very emission intensive in these two regions. The emission-intensive metal sector is also quite large, especially in the Scheldt region. This is partly explained by the favourable locations of industrial zones nearby important shipping routes in these river basins. Indeed, the metal- and chemical sector produce a lot for foreign consumption (exports). Manufacturing in Rhine East, Rhine North and Rhine Central has a less emission-intensive character. Many manufacturing activities in these regions are represented by less emission-intensive industries. The bad environmental efficiency in Scheldt and Ems is partly explained by more flexible environmental regulation directed by local authorities. The emission permissions issued by 'Rijkswaterstaat' (Dutch water regulator) are more flexible in these regions. The license holder fine tunes the permission in accordance with the impact on the aquatic system. The aquatic system in large outside waterways is less vulnerable than small river aquatic systems. Environmental efficiency may have been bad in these regions but the expected environmental performance (i.e. the impact on water quality) could indeed be reasonable. Apparently, the companies in these regions took advantage of these flexible permissions. The analysis done here is based upon initial emissions to water, not on the final impact on water quality.

\subsection{Services}

Lastly, differences between regions in the economic structure of services can have a significant influence on the difference in emission-intensity between regions. Services can strongly be represented by the environmental services or health services in one region while in the other region financial services, retail -and wholesale trade are strongly represented. Environmental services and health services are more emission-intensive than for example financial services, retail -and wholesale trade on average. In order to explain differences in emission-intensity, differences in the structure of services can be a significant explaining factor. For the substances chromium, copper, mercury and nickel hold that the structure of services is a significant factor in explaining differences in emission-intensities between regions. For the other substances hold that differences in the structure of services is not significantly explaining differences in emission-intensity. For the substances arsenic, cadmium, mercury, nickel, phosphorus and nitrogen hold that differences in environmental performance in services is a significant explaining factor for the difference in emission-intensity.

The graphical tool for services is presented in figure 8. This figure presents pollution per euro added value for the different river basins in the years 1995, 2000 and 2005. With regard to the services sector, the emission-intensity in the Scheldt area is extremely high compared to the Dutch average and the other areas. This is explained by the fact that there exists a lot of transport over water in this river basin. Transport over water causes a lot of copper and cadmium emissions due to the anti fouling paint used on boats. A lot of toxic substances are emitted in the Scheldt river basin, while the responsibility for this emission burden, at least for the biggest part, does not lie on Dutch residents but on foreign residents. A lot of these foreign transport boats are crossing the Dutch part of the Scheldt river basin on their way to Antwerp (Belgium) and back. For now, these emissions are attributed to transport over water in the Scheldt river basin. On the other hand, the economic value of the transport activities is based upon the resident principle (in line with the National Accounts) instead of upon the territory principle. This leads to an extremely high emission-intensity of the transport over water sector in the Scheldt river basin. This emission-intensity must be interpreted very carefully because the ratio is based upon two different principles. In the future a method for differentiating 'residents emissions' and 'non-residents emissions' needs to be developed in order to correct for this statistical mismatch related to emissions of 
transport over water. The emission-intensity of river basin Meuse is also quite high. This is explained by the relatively low emission efficiency of the environmental services sector.

\section{Conclusion}

Differences in economic structure have an important role in explaining the variance in emission-intensity between regions. Even if one corrects for differences in economic structure, differences in emission intensity remain. This leads us to believe that a difference in environmental efficiency of industries between river basins also plays an important role. In this paper it has been tested which factors play a significant role in explaining differences in emission-intensity. It is important to note that differences in emission-intensities between river basins are very large, especially in agriculture. The differences in emission-intensities for the sector agriculture are much larger than the differences seen in manufacturing and services. This indicates that the structures of the agricultural sector as well as the environmental performance of a particular sub sector of agriculture are both very important indicators for the overall emission intensity of a particular region.

The emission-intensity for the sector agriculture in Rhine-West is lower than the Dutch average, which is explained by the large horticulture sector in this area. This sector is creating a lot of value added while emissions to water are relatively small. In contrast, arable farming is relatively large in the Ems river basin. This sub sector of agriculture creates relatively little value added while the activities go along with a lot of emissions to water. Here the economic structure plays an important role in explaining overall emission-intensity. Transportation of produced manure is a way to improve environmental efficiency of agriculture in one region. Still this measurement creates an environmental problem for another region.

Manufacturing in Ems and Scheldt emit more to water per euro value added created than the Dutch average. This is explained by the large chemical sector which is quite emission intensive in these two regions. The metal sector is also quite large here, especially in the Scheldt region. This is partly explained by the favourable locations of industrial zones nearby important shipping routes in these river basins. Bad environmental efficiency of manufacturing in Scheldt and Ems is partly explained by more flexible environmental regulation directed by local authorities.

With regard to the services sector, the emission-intensity in the Scheldt area is extremely high compared with the Dutch average and the other areas. This is explained by the fact that there exist a lot of transport over water activities in this river basin. Here a statistical problem needs to be solved. The economic value of the transport activities at river basin level is based upon the resident principle while the calculation of emissions is based upon the territory principle. A recommendation would be to construct a method for differentiating 'residents emissions' and 'non-residents emissions' related to emissions of transport over water at river basin level.

Differences in emission-intensity are explained by various factors. Some factors have significant impact while other factors don't explain the difference in emission-intensity significantly. The factors which explain the differences are very 'substance' dependent. What holds for substance $\mathrm{X}$ does not necessary hold for substance $\mathrm{Y}$. This conclusion leads to the recommendation that emissions to water and water quality should be analysed at river basin level and at substance level. Problems related to water emissions cannot properly be analysed if one looks at national data and to emissions of heavy metal equivalents and nutrients equivalents only. Data at river basin level can help to get a better picture of the problems in the river basin and can ultimately help in developing better water quality measurements for the river basin. Data at national level alone is not sufficient in developing these policies. The availability of economic and emission data at river basin level is vital in developing and implementing emission reduction programmes at minimum costs to society as a whole.

\section{References}

Adriaanse, A. (1993). Environmental policy performance indicators, The Netherlands Ministry of

Housing, spatial planning and the environment, The Hague.

Brouwer, R., Schenau, S. and Van Veeren, R. (2005). Integrated river basin accounting in the Netherlands and the European Water Framework Directive, Statistical Journal of the United Nations ECE, 22, 111-131, IOS Press.

CBS (2007). Monitor Mineralen en Mestwetgeving, Voorburg/Heerlen. Available at CBS: http://www.cbs.nl/NR/rdonlyres/653A0221-263B-400A-921F-BAD600D3775F/0/2007j64pub.pdf

CBS (2008). Milieurekeningen 2007, Voorburg/Heerlen. Available at CBS: http://www.cbs.nl/NR/rdonlyres/1CEEE02D-9C9A-423D-ACB0-3B0EDABF247E/0/2007c167pub.pdf

Dunn, E.S. (1960). A statistical and analytical technique for regional analysis, Papers for the Regional Science Association, 6, 97-112.

Esteban, J. (2000). Regional convergence in Europe and the industry mix: a shift share analysis, Regional science and urban economics, 30, 353-364. 
Haan, M., de (1997). Water in the Dutch national accounts: a 'NAMWA' for 1991. Internal report, Statistics Netherlands, Voorburg.

Haan, M. de., Keuning S.J., and Bosch, P.R. (1994). Integrating indicators in a NationalAccounting Matrix including Environmental Accounts (NAMEA); an application to The Netherlands, National accounts occasional papers, NA-60, Statistics Netherlands.

Haan, M.,de, and Keuning, S.J. (1996). Taking the environment into account; the NAMEA-approach, The Review of Income and Wealth, Series 42, Number 2.

LEI (2006). Regionale anticipatie mestbeleid op Kaderrichtlijn water, Den Haag. Available at LEI: http://www.lei.wur.nl/NL/publicaties+en+producten/LEIpublicaties/?id=678

Mazzanti, M., and Montini, A. (2009). Regional and Sector Environmental Efficiency Empirical Evidence from Structural Shift-Share Analysis of NAMEA Data. FEEM Working Paper No. 11.2009. Available at SSRN: http://ssrn.com/abstract=1395706.

UNSD (2006). Integrated Environmental and Economic Accounting for Water Resources. Draft for Discussion. United Nations Statistics Division. Available at UN: http://unstats.un.org/unsd/envaccounting/SEEAWDraftManual.pdf

United Nations (1993). International Monetary Fund, Organisation for Economic Cooperationand Development, World Bank and Commission of the European Communities, System of National Accounts 1993, Brussels/Luxembourg, New York, Paris, Washington D.C. Available at UN:http://unstats.un.org/ unsd/sna1993/toctop.asp

United Nations (2003). European Commission, International Monetary Fund, Organisation for Economic Co-operation and Development, World Bank, Integrated Environmental and Economic Accounting 2003, Brussels/Luxembourg, New York, Paris, Washington D.C. Available at UN:http://unstats.un.org/ unsd/envaccounting/seea2003.pdf

Websites: www.emissieregistratie.nl

\section{Notes}

Note 1. Both authors are statisticians at the Dutch Bureau of Statistics, CBS. The views expressed in this paper are those of the authors only and do not necessarily reflect the opinion of Statistics Netherlands.

Note 2. The NAMWA is developed in close cooperation with the Water Service (former RIZA).

Table 1. share in total value added per river basin

\begin{tabular}{lrrr}
\hline \multicolumn{1}{c}{ River basin } & Agriculture & Manufacturing & Services \\
\hline Meuse & $3 \%$ & $31 \%$ & $66 \%$ \\
Rhine-West & $2 \%$ & $17 \%$ & $80 \%$ \\
Scheldt & $5 \%$ & $42 \%$ & $53 \%$ \\
Ems & $3 \%$ & $33 \%$ & $64 \%$ \\
Rhine-East & $4 \%$ & $29 \%$ & $67 \%$ \\
Rhine-North & $6 \%$ & $34 \%$ & $60 \%$ \\
Rhine-Central & $3 \%$ & $19 \%$ & $78 \%$ \\
\hline
\end{tabular}

Table 2. share in total emissions per river basin (heavy metals, see appendix 2 for data at substance level)

\begin{tabular}{lrrr}
\hline \multicolumn{1}{c}{ River basin } & Agriculture & Manufacturing & Services \\
\hline Meuse & $13 \%$ & $24 \%$ & $63 \%$ \\
Rhine-West & $18 \%$ & $15 \%$ & $67 \%$ \\
Scheldt & $18 \%$ & $23 \%$ & $59 \%$ \\
Ems & $23 \%$ & $48 \%$ & $30 \%$ \\
Rhine-East & $31 \%$ & $16 \%$ & $53 \%$ \\
Rhine-North & $53 \%$ & $12 \%$ & $36 \%$ \\
Rhine-Central & $28 \%$ & $12 \%$ & $61 \%$ \\
\hline
\end{tabular}


Table 3. Results of linear regression analysis

\begin{tabular}{|c|c|c|c|c|c|c|c|c|c|c|c|c|}
\hline & Agriculture & Beta & $T$-value & Sig & Manufacturing & Beta & $T$-value & Sig & Services & Beta & $T$-value & Sig \\
\hline \multirow[t]{10}{*}{ Industry mix } & Arsine & 0,065 & 0,580 & 0,568 & Arsine & 0,469 & 3,546 & $0,002^{*}$ & Arsine & 0,308 & 1,728 & 0,099 \\
\hline & Cadmium & 0,024 & 0,736 & 0,470 & Cadmium & 0,177 & 6,223 & $0^{*}$ & Cadmium & 0,003 & 0,083 & 0,934 \\
\hline & Chrome & $-0,221$ & $-0,411$ & 0,685 & Chrome & $-0,482$ & $-1,709$ & 0,102 & Chrome & 0,601 & 2,271 & 0,034 \\
\hline & Copper & 0,283 & 3,744 & $0,001^{*}$ & Copper & 0,458 & 8,461 & $0^{*}$ & Copper & 0,879 & 8,232 & $0 *$ \\
\hline & Mercury & - & - & - & Mercury & $-0,042$ & $-0,552$ & 0,586 & Mercury & 0,325 & 3,027 & 0,006 \\
\hline & Lead & 0,486 & 4,833 & $0^{*}$ & Lead & $-0,049$ & $-0,612$ & 0,547 & Lead & $-0,068$ & $-0,743$ & 0,466 \\
\hline & Nickel & 0,343 & 2,556 & 0,018 & Nickel & $-0,060$ & $-0,424$ & 0,676 & Nickel & 0,533 & 3,630 & $0,002 *$ \\
\hline & Zinc & $-0,100$ & $-0,605$ & 0,551 & Zinc & $-0,013$ & $-0,088$ & 0,931 & Zinc & 0,281 & 1,188 & 0,248 \\
\hline & Phosphorus & 0,064 & 2,881 & 0,009 & Phosphorus & 0,014 & 0,739 & 0,468 & Phosphorus & 0,009 & 0,389 & 0,701 \\
\hline & Nitrogen & 0,683 & 14,968 & $0^{*}$ & Nitrogen & 0,025 & 0,590 & 0,562 & Nitrogen & 0,014 & 0,321 & 0,752 \\
\hline \multirow[t]{10}{*}{ Efficiency } & Arsine & $-0,071$ & $-0,519$ & 0,609 & Arsine & 0,186 & 1,754 & 0,094 & Arsine & 0,407 & 3,530 & $0,002^{\star}$ \\
\hline & Cadmium & 0,187 & 3,718 & $0,001^{*}$ & Cadmium & 0,765 & 13,718 & $0^{*}$ & Cadmium & 0,138 & 4,422 & $0 *$ \\
\hline & Chrome & 0,055 & 0,110 & 0,913 & Chrome & $-0,025$ & $-0,124$ & 0,902 & Chrome & 0,172 & 0,524 & 0,606 \\
\hline & Copper & $-0,148$ & $-1,206$ & 0,241 & Copper & $-0,009$ & $-0,147$ & 0,885 & Copper & $-0,074$ & $-1,333$ & 0,197 \\
\hline & Mercury & - & - & - & Mercury & 0,896 & 13,734 & $0^{*}$ & Mercury & 0,772 & 6,767 & $0 *$ \\
\hline & Lead & 0,547 & 5,066 & $0^{*}$ & Lead & 0,214 & 3,069 & 0,006 & Lead & $-0,028$ & $-0,368$ & 0,716 \\
\hline & Nickel & 0,359 & 2,458 & 0,023 & Nickel & $-0,007$ & $-0,055$ & 0,956 & Nickel & 0,564 & 3,694 & $0,001^{*}$ \\
\hline & Zinc & 0,551 & 2,059 & 0,052 & Zinc & 0,950 & 0,967 & 0,345 & Zinc & 0,233 & 1,866 & 0,076 \\
\hline & Phosphorus & 0,571 & 7,550 & $0^{*}$ & Phosphorus & 0,156 & 6,764 & $0^{*}$ & Phosphorus & 0,362 & 4,956 & $0 *$ \\
\hline & Nitrogen & 0,432 & 6,974 & $0^{*}$ & Nitrogen & $-0,016$ & $-0,372$ & 0,714 & Nitrogen & 0,134 & 2,587 & 0,017 \\
\hline
\end{tabular}

Results of linear regression analysis

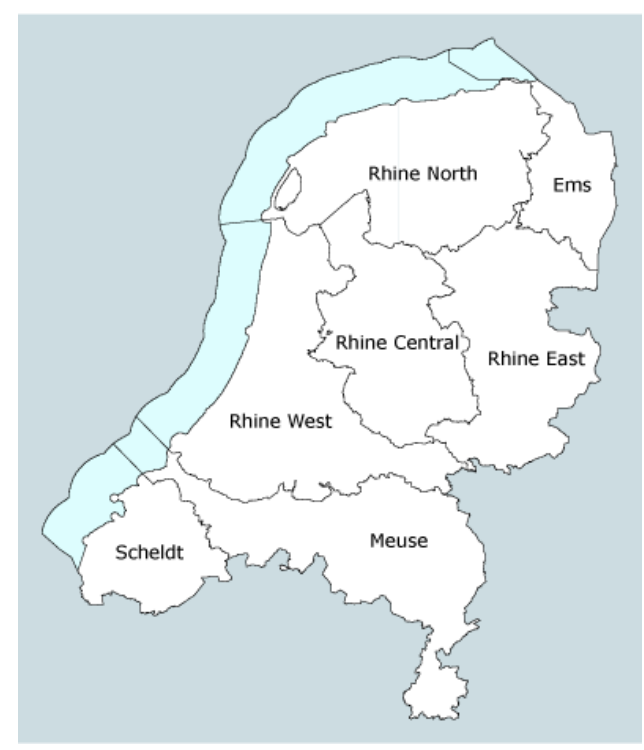

Figure 1. The Dutch main river basin districts (Source: website CBS) 
Value added and emissions to water in 2005

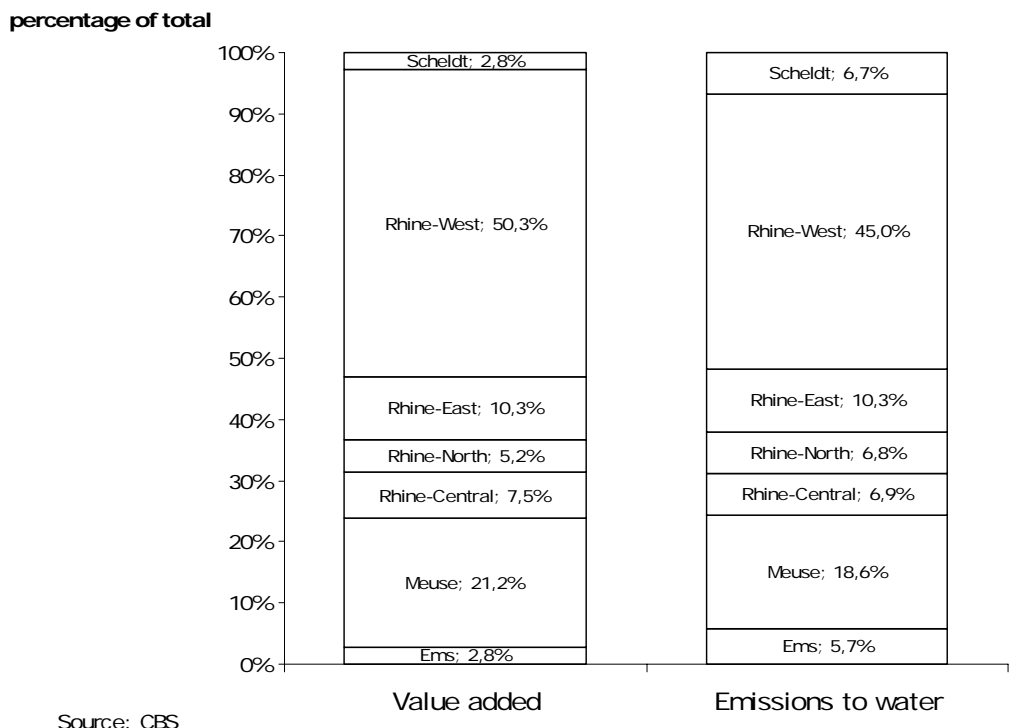

Figure 2. Value added and emissions to water in the various river basins, 2005

Value added and emissions to water, 1995-2005

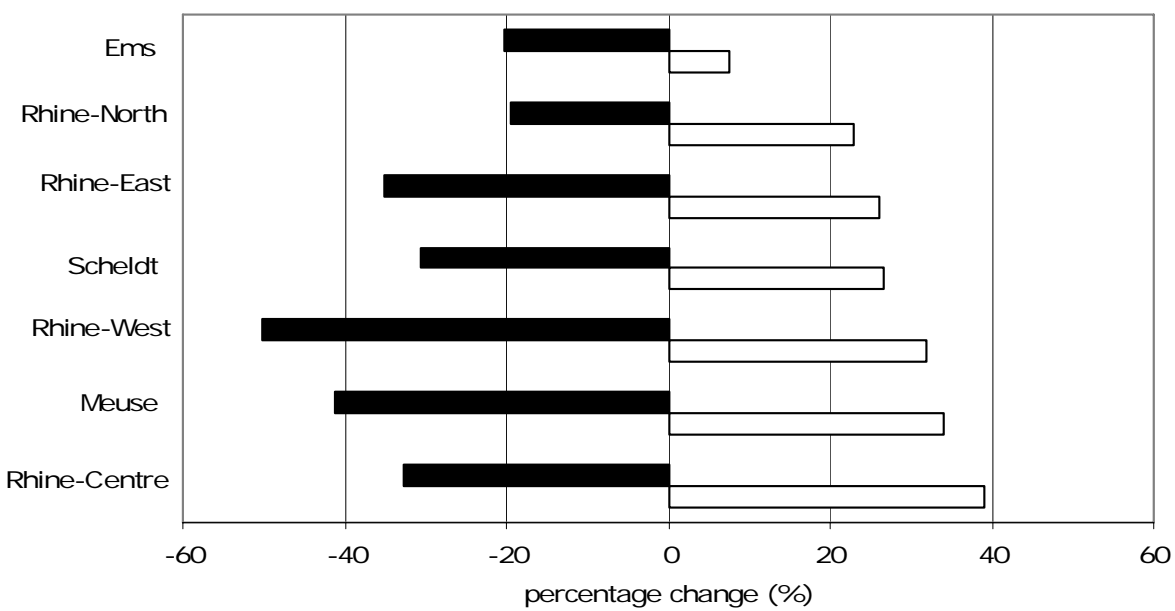

Source: CBS

¿ Economic growth, 1995-2005 — Development in emissions to water, 1995-2005

Figure 3. Value added and emissions to water in the various river basins, 1995-2005 


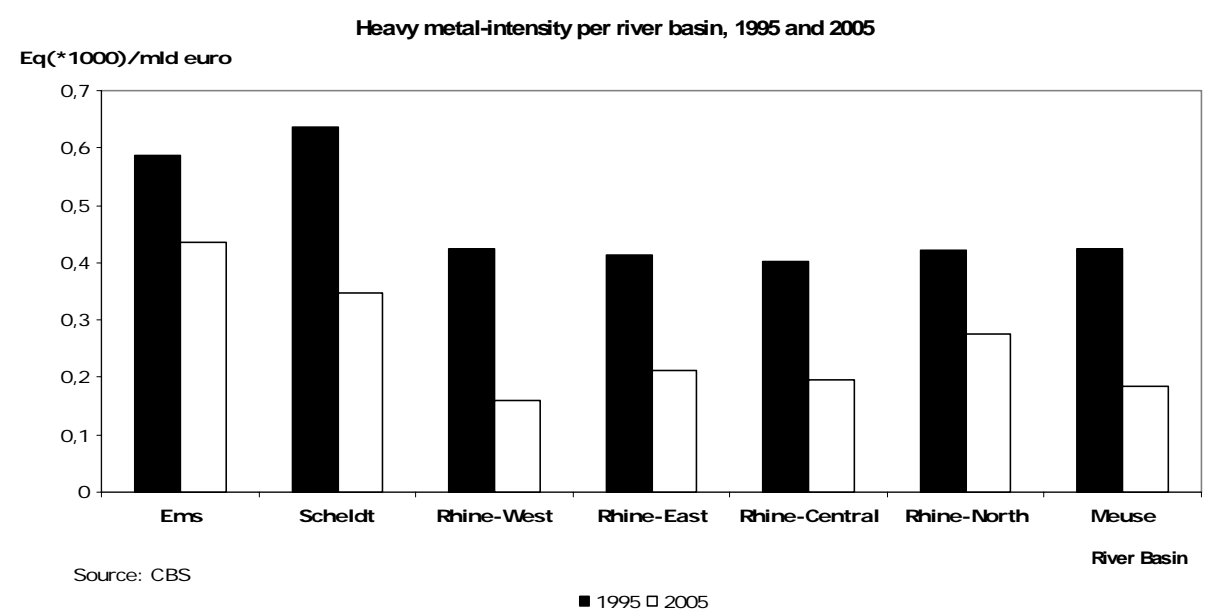

Figure 4. Emission intensity in the various river basins, 1995 and 2005

\section{Emission-intensity region i minus emission-entensity The Netherlands}

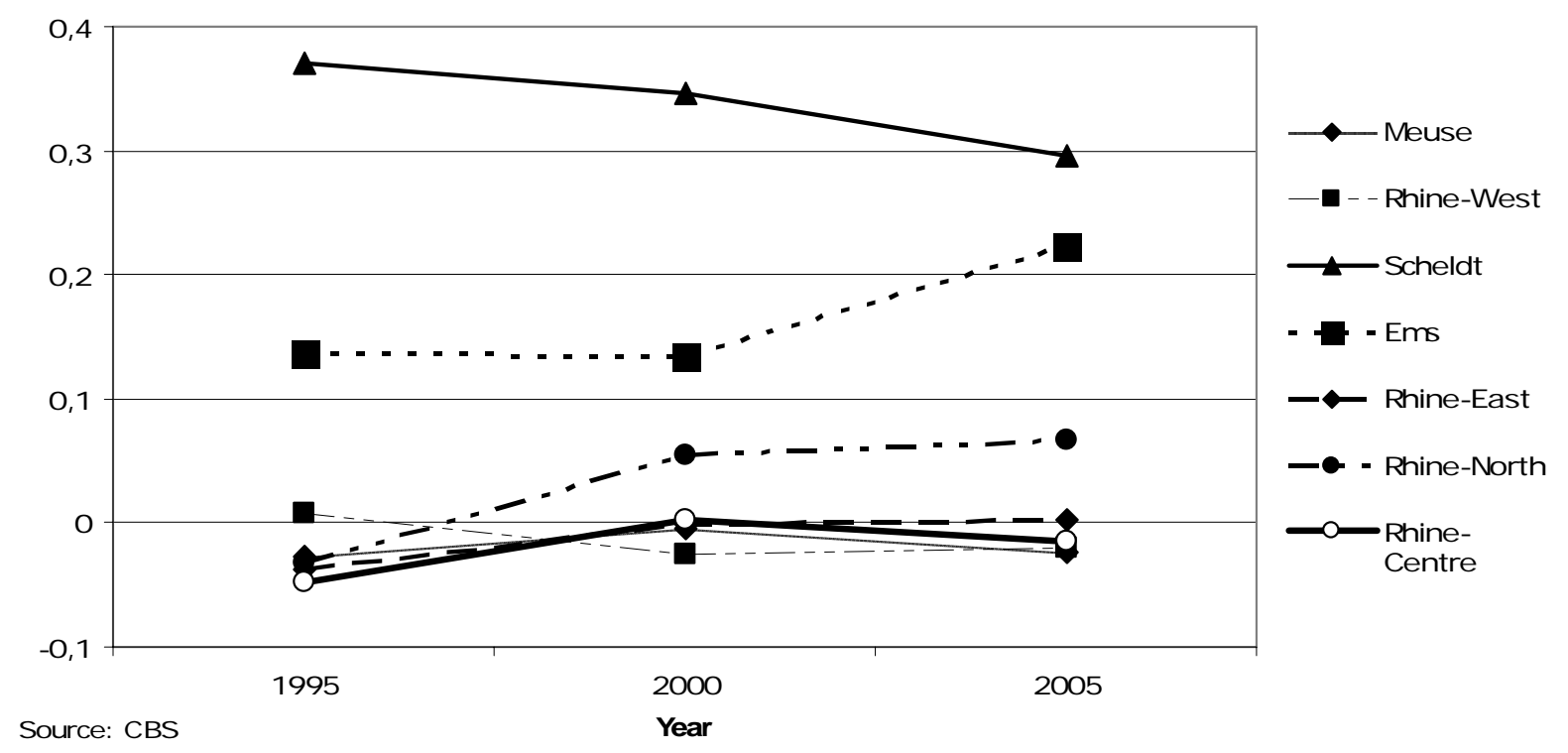

Figure 5. Emission-intensity of the various river basins 1995-2005 
Emission-intensity region i minus emission-intensity Netherlands, Agriculture 1995, 2000, 2005

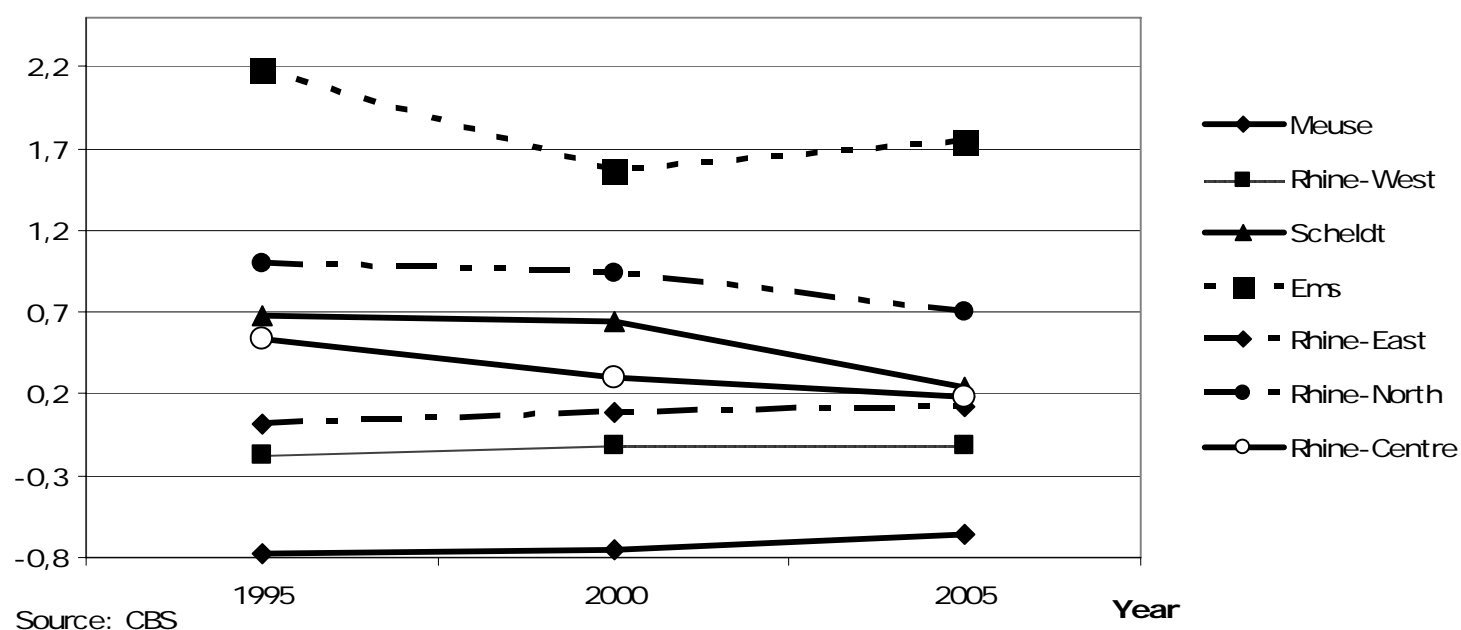

Figure 6. Pollution per euro added value for the various river basins in the years 1995, 2000 and 2005, agriculture

\section{Emission-intensity region i minus emission-intensity Netherlands, Manufacturing,} 1995, 2000, 2005

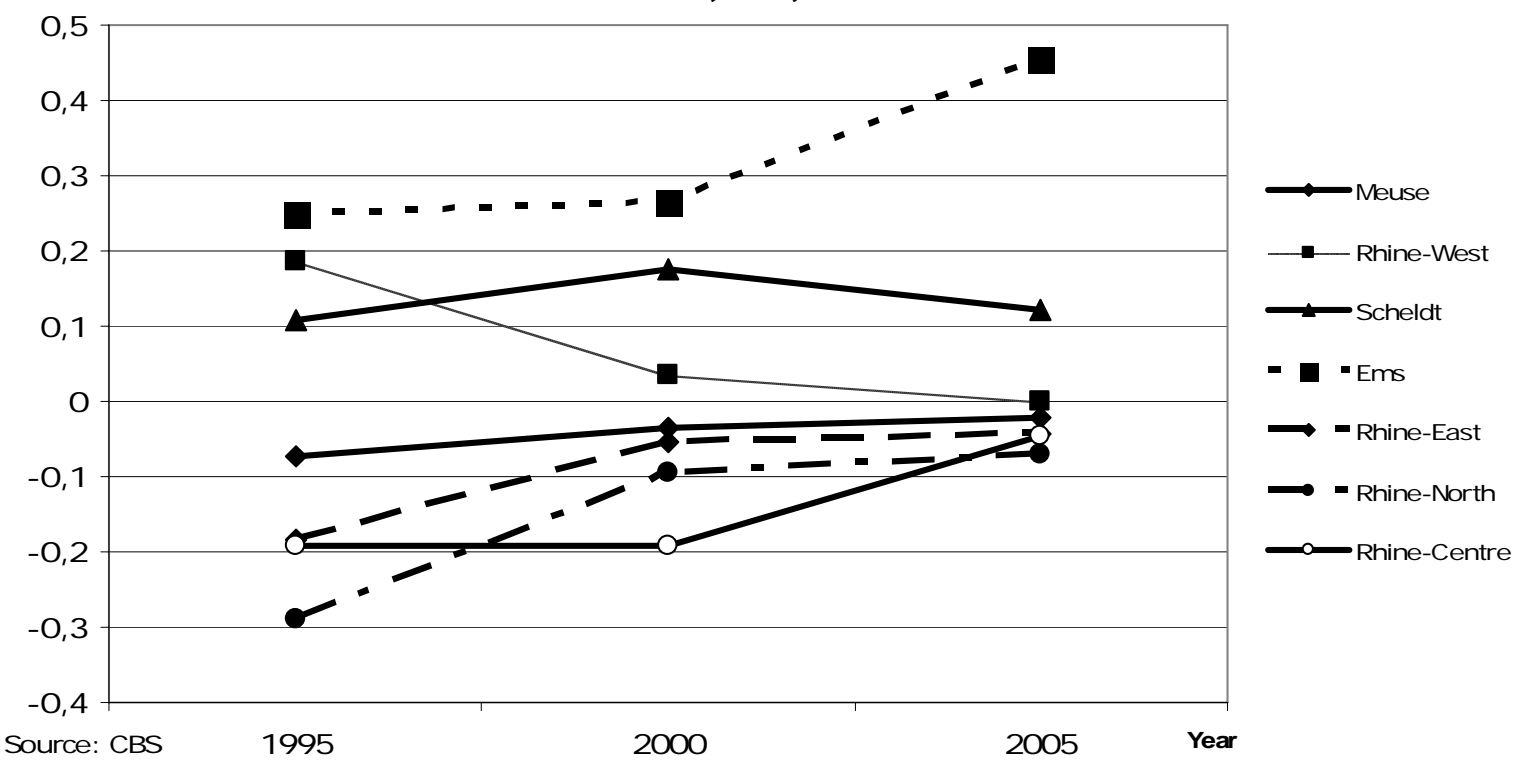

Figure 7. Pollution per euro added value for the various river basins in the years 1995, 2000 and 2005, manufacturing 


\section{Emission-intensity region i minus emission-intensity Netherlands, Services, 1995, 2000, 2005}

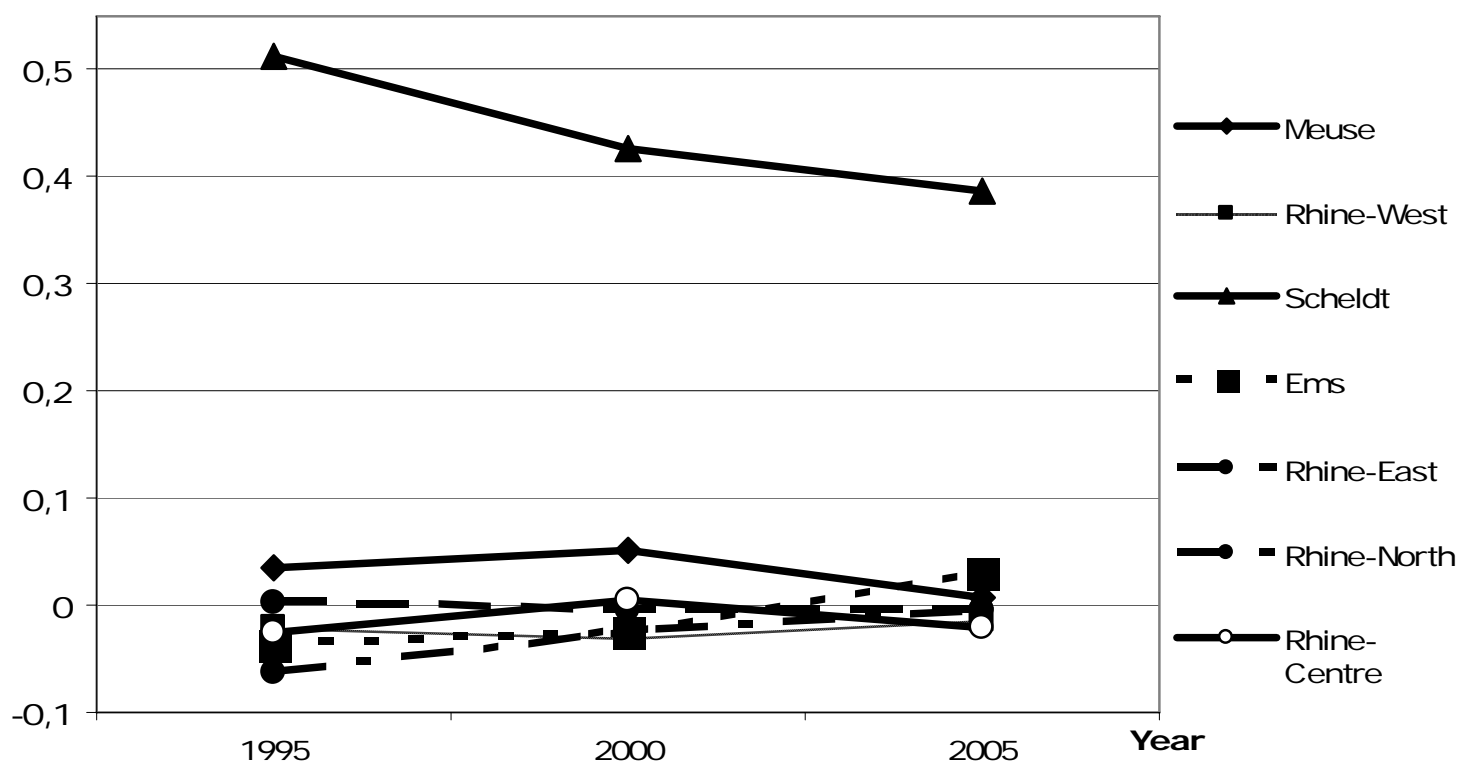

Source: CBS

Figure 8. Pollution per euro added value for the various river basins in the years 1995, 2000 and 2005, services

\section{Appendix 1}

$M_{r}^{I}=\sum_{I}\left(P_{r}^{I}-P_{n l}^{I}\right) X^{I}$, industry mix effect of manufacturing

$M_{r}^{S}=\sum_{S}\left(P_{r}^{S}-P_{n l}^{S}\right) X^{S}$, industry mix effect of services

$P_{r}^{I}=\sum_{I} P_{n l}{ }^{I}\left(X_{r}^{I}-X_{n l}{ }^{I}\right)$, efficiency effect of manufacturing

$P_{r}^{S}=\sum_{S} P_{n l}^{S}\left(X_{r}^{S}-X_{n l}{ }^{S}\right)$, efficiency effect of services

$Q_{r}^{I}=\frac{E_{r}^{I}}{E_{r}}$, share of emissions of manufacturing in total emissions in region $r$

$Q_{r}^{S}=\frac{E_{r}^{S}}{E_{r}}$, share of emissions of services in total emissions in region $r$

$Z_{r}^{I}=\frac{Y_{r}^{I}}{Y_{r}}$, share of value added of manufacturing in total value added in region $r$

$Z_{r}^{S}=\frac{Y_{r}^{S}}{Y_{r}}$, share of value added of services in total value added in region $r$ 


\section{Appendix 2}

Share in total emissions per river basin (data at substance level)

\begin{tabular}{|c|c|c|c|c|c|c|c|}
\hline Substance & Maas_Agriculture & RijnWest_Agriculture & Schelde_Agriculture & Eems_Agriculture & RijnOost_Agriculture & RijnNoord_Agriculture & RijnMidden_Agriculture \\
\hline Arsenic & $0 \%$ & $0 \%$ & $0 \%$ & $0 \%$ & $0 \%$ & $0 \%$ & $0 \%$ \\
\hline Cadmium & $41 \%$ & $20 \%$ & $11 \%$ & $19 \%$ & $67 \%$ & $71 \%$ & $37 \%$ \\
\hline Chromium & $0 \%$ & $0 \%$ & $0 \%$ & $0 \%$ & $0 \%$ & $0 \%$ & $0 \%$ \\
\hline Copper & $13 \%$ & $5 \%$ & $17 \%$ & $18 \%$ & $31 \%$ & $55 \%$ & $34 \%$ \\
\hline Mercury & $0 \%$ & $0 \%$ & $0 \%$ & $0 \%$ & $0 \%$ & $0 \%$ & $0 \%$ \\
\hline Lead & $70 \%$ & $38 \%$ & $82 \%$ & $71 \%$ & $84 \%$ & $87 \%$ & $77 \%$ \\
\hline Nickel & $15 \%$ & $8 \%$ & $37 \%$ & $38 \%$ & $52 \%$ & $71 \%$ & $52 \%$ \\
\hline Zinc & $19 \%$ & $9 \%$ & $24 \%$ & $42 \%$ & $50 \%$ & $78 \%$ & $41 \%$ \\
\hline Phosperus & $27 \%$ & $15 \%$ & $43 \%$ & $58 \%$ & $38 \%$ & $55 \%$ & $72 \%$ \\
\hline Nitrogen & $54 \%$ & $37 \%$ & $69 \%$ & $58 \%$ & $69 \%$ & $77 \%$ & $72 \%$ \\
\hline Substance & Maas_Manufacturing & RijnWest_Manufacturing & Schelde_Manufacturing & Eems_Manufacturing & RijnOost_Manufacturing & RijnNoord_Manufacturing & RijnMidden_Manufacturing \\
\hline Arsenic & $18 \%$ & $11 \%$ & $28 \%$ & $43 \%$ & $3 \%$ & $1 \%$ & $3 \%$ \\
\hline Cadmium & $14 \%$ & $14 \%$ & $56 \%$ & $66 \%$ & $6 \%$ & $2 \%$ & $10 \%$ \\
\hline Chromium & $80 \%$ & $87 \%$ & $79 \%$ & $91 \%$ & $84 \%$ & $77 \%$ & $85 \%$ \\
\hline Copper & $38 \%$ & $17 \%$ & $24 \%$ & $57 \%$ & $29 \%$ & $20 \%$ & $19 \%$ \\
\hline Mercury & $3 \%$ & $11 \%$ & $35 \%$ & $10 \%$ & $5 \%$ & $0 \%$ & $0 \%$ \\
\hline Lead & $8 \%$ & $8 \%$ & $3 \%$ & $19 \%$ & $3 \%$ & $1 \%$ & $3 \%$ \\
\hline Nickel & $44 \%$ & $32 \%$ & $42 \%$ & $49 \%$ & $28 \%$ & $17 \%$ & $29 \%$ \\
\hline Zinc & $20 \%$ & $10 \%$ & $12 \%$ & $38 \%$ & $10 \%$ & $4 \%$ & $8 \%$ \\
\hline Phosperus & $31 \%$ & $19 \%$ & $34 \%$ & $10 \%$ & $24 \%$ & $28 \%$ & $9 \%$ \\
\hline Nitrogen & $20 \%$ & $15 \%$ & $11 \%$ & $13 \%$ & $13 \%$ & $10 \%$ & $9 \%$ \\
\hline Substance & Maas_Services & RijnWest_Services & Schelde_Services & Eems_Services & RijnOost_Services & RijnNoord_Services & RijnMidden_Services \\
\hline Arsenic & $82 \%$ & $89 \%$ & $72 \%$ & $57 \%$ & $97 \%$ & $99 \%$ & $97 \%$ \\
\hline Cadmium & $45 \%$ & $69 \%$ & $33 \%$ & $15 \%$ & $27 \%$ & $26 \%$ & $53 \%$ \\
\hline Chromium & $20 \%$ & $13 \%$ & $21 \%$ & $9 \%$ & $16 \%$ & $23 \%$ & $15 \%$ \\
\hline Copper & $49 \%$ & $61 \%$ & $59 \%$ & $24 \%$ & $41 \%$ & $25 \%$ & $47 \%$ \\
\hline Mercury & $97 \%$ & $89 \%$ & $65 \%$ & $90 \%$ & $95 \%$ & $100 \%$ & $100 \%$ \\
\hline Lead & $22 \%$ & $26 \%$ & $15 \%$ & $10 \%$ & $14 \%$ & $12 \%$ & $20 \%$ \\
\hline Nickel & $41 \%$ & $17 \%$ & $21 \%$ & $13 \%$ & $20 \%$ & $11 \%$ & $20 \%$ \\
\hline Zinc & $61 \%$ & $57 \%$ & $65 \%$ & $20 \%$ & $40 \%$ & $18 \%$ & $51 \%$ \\
\hline Phosperus & $42 \%$ & $36 \%$ & $24 \%$ & $33 \%$ & $38 \%$ & $16 \%$ & $19 \%$ \\
\hline Nitrogen & $26 \%$ & $41 \%$ & $20 \%$ & $28 \%$ & $17 \%$ & $13 \%$ & $19 \%$ \\
\hline
\end{tabular}




\section{Appendix 3}

Output for the Scheldt region in 2005 (other river basins for all years available on request)

\begin{tabular}{|c|c|c|c|c|c|c|c|c|c|c|c|}
\hline \multicolumn{2}{|c|}{ Total economy 2005} & \multirow{2}{*}{$\begin{array}{c}\mathrm{Xr} \\
0.005478\end{array}$} & \multirow{2}{*}{$\frac{\mathrm{Xnl}}{0.002232}$} & \multirow{2}{*}{$\frac{\text { Xr-Xnl }}{0.003246}$} & \multirow{2}{*}{$\begin{array}{r}\text { Difference (\%) } \\
145 \%\end{array}$} & \multirow{2}{*}{$\frac{\mathrm{m}}{0.000947}$} & \multirow{2}{*}{$\frac{p}{0.002435}$} & \multirow{2}{*}{$\frac{\mathbf{a}}{-0.000137}$} & \multirow{2}{*}{$\frac{m+p+a}{0.003246}$} & \multirow{2}{*}{$\frac{\text { sector }}{\text { tal economy }}$} & \multirow{2}{*}{$\frac{\text { year }}{2005}$} \\
\hline 103 & Arsenic & & & & & & & & & & \\
\hline 104 & Cadmium & 0.024422 & 0.010324 & 0.014098 & $137 \%$ & 0.014568 & 0.005299 & -0.005769 & 0.014098 & Total economy & 2005 \\
\hline 105 & Chromium & 0.004271 & 0.003092 & 0.001179 & $38 \%$ & 0.0031 & 0.00333 & -0.005251 & 0.00 & Total economy & 2005 \\
\hline 109 & Copper & 0.260757 & 0.095475 & 0.165282 & $173 \%$ & 0.093475 & 0.215098 & -0.14331 & 0.165263 & Total economy & 2005 \\
\hline 110 & Mercury & 0.065325 & 0.051539 & 0.013785 & $27 \%$ & 0.005471 & 0.010649 & -0.002335 & 0.013785 & Total economy & 2005 \\
\hline 111 & Lead & 0.011537 & 0.007204 & 0.004332 & $60 \%$ & 0.005801 & 0.00802 & -0.00949 & 0.004332 & Total ec & 2005 \\
\hline 114 & Nickel & 0.2309 & 0.135039 & 0.095861 & $71 \%$ & 0.107983 & 0.28396 & -0.00949 & 0.3 & Total e & 2005 \\
\hline 120 & Zinc & 0.134558 & 0.040587 & 0.093971 & $232 \%$ & 0.032916 & 0.117648 & -0.056598 & 0.0 & Total e & 2005 \\
\hline 302 & Phosporus & 49.21718 & 22.25355 & 26.96363 & $121 \%$ & 17.95157 & 25.03855 & -16.02649 & 26.96363 & Total economy & 2005 \\
\hline 303 & Nitrogen & 43.14165 & 23.45792 & 19.68374 & $84 \%$ & 15.58417 & 38.72549 & -34.62593 & 19.68374 & Total economy & 2005 \\
\hline ZMEQ & Heavy metalequivalents & 0.506347 & 0.210454 & 0.295894 & $141 \%$ & 0.156278 & 0.362481 & -0.22289 & 0.295869 & Total economy & 2005 \\
\hline NEQ & Nutrientsequivalents & 92.35884 & 45.71147 & 46.64736 & $102 \%$ & 33.53574 & 63.76404 & -50.65242 & 46.64736 & Total economy & 2005 \\
\hline
\end{tabular}

\begin{tabular}{|c|c|c|c|c|c|c|c|c|c|c|}
\hline \multicolumn{2}{|c|}{ Agriculture 2005} & \multirow{2}{*}{$\frac{\mathrm{Xr}}{4.01 \mathrm{E}-07}$} & \multirow{2}{*}{$\frac{\text { Xnl }}{5.09 \mathrm{E}-07}$} & \multirow{2}{*}{$\frac{\mathrm{Xr}-\mathrm{XnI}}{-1.08 \mathrm{E}-07}$} & \multirow{2}{*}{$\begin{array}{r}\text { Difference (\%) } \\
-21 \%\end{array}$} & \multirow{2}{*}{$\frac{\mathbf{m}}{-8.72 \mathrm{E}-08}$} & \multirow{2}{*}{$\frac{\mathbf{p}}{-1.17 \mathrm{E}-08}$} & \multirow{2}{*}{$\frac{\mathbf{a}}{-8.79 \mathrm{E}-09}$} & \multirow{2}{*}{$\begin{array}{cc}\mathbf{m}+\mathbf{p}+\mathbf{a} & \text { sector } \\
-1.08 \mathrm{E}-07 & \text { Agriculture }\end{array}$} & \multirow{2}{*}{$\frac{\text { year }}{2005}$} \\
\hline 103 & Arsenic & & & & & & & & & \\
\hline 104 & Cadmium & 0.051445 & 0.107291 & -0.055846 & $-52 \%$ & 0.021563 & -0.013638 & -0.063771 & -0.055846 Agriculture & 2005 \\
\hline 105 & Chromium & $6.4 \mathrm{E}-06$ & 8.13E-06 & $-1.73 E-06$ & $-21 \%$ & $-1.4 \mathrm{E}-06$ & $-1.87 \mathrm{E}-07$ & $-1.4 \mathrm{E}-07$ & -1.73E-06 Agriculture & 2005 \\
\hline 109 & Copper & 0.910747 & 0.763125 & 0.147622 & $19 \%$ & 0.422352 & 0.615863 & -0.890593 & 0.147622 Agriculture & 2005 \\
\hline 110 & Mercury & 0 & 0 & 0 & & 0 & 0 & 0 & 0 Agriculture & 2005 \\
\hline 111 & Lead & 0.189245 & 0.182335 & 0.006911 & $4 \%$ & 0.022265 & 0.163299 & -0.178653 & 0.006911 Agriculture & 2005 \\
\hline 114 & Nickel & 1.710241 & 1.99441 & -0.284168 & $-14 \%$ & 0.379503 & 1.160311 & -1.823982 & -0.284168 Agriculture & 2005 \\
\hline 120 & Zinc & 0.634748 & 0.490429 & 0.14432 & $29 \%$ & 0.096053 & 0.659495 & -0.611228 & 0.14432 Agriculture & 2005 \\
\hline 302 & Phosporus & 421.1687 & 314.8025 & 106.3662 & $34 \%$ & 85.67536 & 414.6826 & -393.9918 & 106.3662 Agriculture & 2005 \\
\hline 303 & Nitrogen & 593.683 & 453.5693 & 140.1136 & $31 \%$ & 21.78354 & 682.9827 & -564.6526 & 140.1136 Agriculture & 2005 \\
\hline ZMEQ & Heavy metalequivalents & 1.786193 & 1.543188 & 0.243005 & $16 \%$ & 0.562231 & 1.425018 & -1.744245 & 0.243005 Agriculture & 2005 \\
\hline NEQ & Nutrientsequivalents & 1014.852 & 768.3718 & 246.4799 & $32 \%$ & 107.4589 & 1097.665 & -958.6444 & 246.4799 Agriculture & 2005 \\
\hline \multicolumn{2}{|c|}{ Industry 2005} & $\overline{X r}$ & Xnl & Xr-Xnl & Difference (\%) & $\mathrm{m}$ & $\bar{p}$ & $\bar{a}$ & $m+p+a$ & year \\
\hline 103 & Arsenic & 0.003677 & 0.00124 & 0.002436 & $196 \%$ & 0.001775 & 0.001301 & -0.00064 & 0.002436 Industry & 2005 \\
\hline 104 & Cadmium & 0.032881 & 0.011476 & 0.021405 & $187 \%$ & 0.022683 & 0.011694 & -0.012972 & 0.021405 Industry & 2005 \\
\hline 105 & Chromium & 0.008074 & 0.01085 & -0.002776 & $-26 \%$ & 0.003005 & 0.011575 & -0.017356 & -0.002776 Industry & 2005 \\
\hline 109 & Copper & 0.147997 & 0.09815 & 0.049847 & $51 \%$ & 0.054513 & 0.409256 & -0.413967 & 0.049802 Industry & 2005 \\
\hline 110 & Mercury & 0.054559 & 0.018007 & 0.036552 & $203 \%$ & 0.010538 & 0.054074 & -0.02806 & 0.036552 Industry & 2005 \\
\hline 111 & Lead & 0.000757 & 0.00188 & -0.001123 & $-60 \%$ & 0.002052 & -0.000162 & -0.003016 & -0.001125 Industry & 2005 \\
\hline 114 & Nickel & 0.230526 & 0.190239 & 0.040287 & $21 \%$ & 0.044646 & 0.930546 & -0.934905 & 0.040287 Industry & 2005 \\
\hline 120 & Zinc & 0.03754 & 0.022344 & 0.015196 & $68 \%$ & 0.026393 & 0.168679 & -0.179885 & 0.015186 Industry & 2005 \\
\hline 302 & Phosporus & 39.73077 & 21.39916 & 18.33162 & $86 \%$ & 10.59508 & 30.9378 & -23.20127 & 18.33162 Industry & 2005 \\
\hline 303 & Nitrogen & 11.8523 & 14.1614 & -2.30909 & $-16 \%$ & 8.496041 & 64.31296 & -75.11809 & -2.30909 Industry & 2005 \\
\hline ZMEQ & Heavy metalequivalents & 0.285485 & 0.163947 & 0.121539 & $74 \%$ & 0.120959 & 0.656417 & -0.655896 & 0.12148 Industry & 2005 \\
\hline NEQ & Nutrientsequivalents & 51.58308 & 35.56055 & 16.02253 & $45 \%$ & 19.09112 & 95.25076 & -98.31936 & 16.02253 Industry & 2005 \\
\hline
\end{tabular}

\begin{tabular}{|c|c|c|c|c|c|c|c|c|c|c|}
\hline \multicolumn{2}{|c|}{ Services 2005} & \multirow{2}{*}{$\begin{array}{c}\mathrm{Xr} \\
0.007394\end{array}$} & \multirow{2}{*}{$\begin{array}{c}\text { Xnl } \\
0.00265\end{array}$} & \multirow{2}{*}{$\frac{\text { Xr-Xnl }}{0.004744}$} & \multirow{2}{*}{$\begin{array}{r}\text { Difference (\%) } \\
179 \%\end{array}$} & \multirow{2}{*}{$\frac{\mathbf{m}}{0.000954}$} & \multirow{2}{*}{$\begin{array}{c}\mathbf{p} \\
0.002908\end{array}$} & \multirow{2}{*}{$\frac{\mathbf{a}}{0.000882}$} & \multirow{2}{*}{$\frac{\text { sector }}{\text { rvices }}$} & \multirow{2}{*}{$\begin{array}{l}\text { year } \\
2005\end{array}$} \\
\hline 103 & Arsenic & & & & & & & & & \\
\hline 104 & Cadmium & 0.015302 & 0.006008 & 0.009294 & $155 \%$ & 0.001943 & 0.003958 & 0.003392 & 0.009294 Services & 2005 \\
\hline 105 & Chromium & 0.001704 & 0.000657 & 0.001047 & $159 \%$ & 0.000139 & 0.000745 & 0.000163 & 0.001047 Services & 2005 \\
\hline 109 & Copper & 0.287916 & 0.067492 & 0.220424 & $327 \%$ & 0.056612 & 0.134776 & 0.029036 & 0.220424 Services & 2005 \\
\hline 110 & Mercury & 0.079822 & 0.064694 & 0.015128 & $23 \%$ & 0.019835 & -0.003245 & -0.001462 & 0.015128 Services & 2005 \\
\hline 111 & Lead & 0.003332 & 0.001852 & 0.00148 & $80 \%$ & 0.00032 & 0.004417 & -0.003258 & 0.00148 Services & 2005 \\
\hline 114 & Nickel & 0.092934 & 0.041354 & 0.05158 & $125 \%$ & 0.008861 & 0.035071 & 0.007648 & 0.05158 Services & 2005 \\
\hline 120 & Zinc & 0.163444 & 0.028346 & 0.135098 & $477 \%$ & 0.016522 & 0.078819 & 0.039758 & 0.135098 Services & 2005 \\
\hline 302 & Phosporus & 21.85045 & 10.66068 & 11.18976 & $105 \%$ & 2.27481 & 7.276407 & 1.638546 & 11.18976 Services & 2005 \\
\hline 303 & Nitrogen & 16.0814 & 9.066465 & 7.014934 & $77 \%$ & 1.971723 & 4.133045 & 0.910166 & 7.014934 Services & 2005 \\
\hline ZMEQ & Heavy metalequivalents & 0.558915 & 0.1717 & 0.387215 & $226 \%$ & 0.096326 & 0.222378 & 0.068511 & 0.387215 Services & 2005 \\
\hline NEQ & Nutrientsequivalents & 37.93184 & 19.72715 & 18.2047 & $92 \%$ & 4.246533 & 11.40945 & 2.548712 & 18.2047 Services & 2005 \\
\hline
\end{tabular}

